\title{
'n Semiotiese ontleding van Daniël 1
}

\author{
Marius $\mathrm{Nel}^{1}$ \\ Noordwes-Universiteit (Potchefstroom Kampus)
}

\begin{abstract}
A Semiotic analysis of Daniel 1

In this article the method of semiotic analysis is used in interpreting Daniel 1. At first, a short summary is given of the procedure before it is applied in a discussion of Daniel 1. Semiotics allows the researcher to analyze the functions and qualifications in the narrative in order to define pertinent transformations. In the process the role-players and plot are analyzed, leading to presentation of semiotic squares and the way the writer transfers values and convictions. The narrative programs are described, and the themes and characters identified. The important themes are the sovereignty of Israel's God and responsibility of believers.
\end{abstract}

\section{SEMIOTIEK}

In hierdie artikel word Daniël 1 semioties ontleed, met die doel om aan te toon watter gevolgtrekkinge alles hieruit gemaak kan word. Voor die ontleding is dit nodig dat 'n kort omskrywing van die werkswyse van semiotiek gedoen word. "Semiotiek" verwys na die studie van die struktuur van tekens, sowel as van die verskynsel van kommunikasie in terme van 'n teorie oor die aard van tekens (Milne 1988:43-65; Atkins \& Morrow 1989). "Semiotiese ontleding" is die studie van die formele netwerke van verhoudings van die tekens binne 'n verhaal, wat universeel is. Dit beteken dat die skrywer sowel as leser dit herken en begryp (Culley 1972:139; Jacobson 1974:156; Spivey 1974:105).

Semiotiek berus op die beginsel dat die elementêre struktuur van betekenis uit verskille en teenoorgesteldes bestaan (Amerding 1997:78). Daar is geen betekenis sonder die basis van verskille nie (Culley 1992:10). Die betekenis-gewende verskynsels word herken deur die pertinente onderlinge verskille tussen elemente te beskryf en te evalueer (Calloud 1976:5). Die doel van struktuur-analise is die sistematiese bestudering van simboliese of konnotatiewe dimensies in tekste. Dit ontsluit die mag van tekste, wat die sleutel tot die suksesvolle kommunikasie van die tekste is (Patte \& Patte

\footnotetext{
${ }^{1} \mathrm{Dr}$ Marius Nel is 'n buitengewone senior lektor by die Skool vir Bybelwetenskappe en Bybeltale, Noordwes-Universiteit (Potchefstroom Kampus).
} 


\section{'n Semiotiese ontleding van Daniël 1}

1978:4). Die leser "ontvang" die inligting en maak daarvan gebruik, en aanvaar die opdragte wat dit gee. Dit gebeur egter slegs as die teks sy mag op die leser uitgeoefen het, of anders gestel, as die leser die visie van lewe wat die teks bied (of die wêreldbeeld daarvan) aanvaar. Struktuur-analise lê die stelsel van diep waardes, of oortuigings, wat deur die teks afgedwing word, bloot. Dié stelsel het die mag om onwerklikheid in werklikheid te omskep. Die stelsels van oortuigings is die raamwerk waarbinne die mens sy diskoerse en lewe sinvol laat ontvou. Bybelse strukturele eksegese wil verder gaan deur godsdienstige manifestasies se rol om stelsels van oortuigings te vestig en oor te dra, te beskryf (vgl. Culley 1974; Polzin 1975; Calloud 1976, 1992; Patte \& Patte 1978).

Nog 'n beginsel is dat die beweging van die uitdrukking (betekenisgewer) na die inhoud (betekenis) die essensiële probleem van alle tekenstelsels vorm. Dié beweging is nie 'n woord-vir-woord ooreenkoms nie. Dit is eerder die spel van ekwivalente tussen stelsels van verhoudings (Muilenberg 1969:8-10; Weiss 1972:88; Polzin 1975:178; Calloud 1992:122).

\section{2. 'N WERKWYSE VAN SEMIOTIESE ONTLEDING}

\subsection{Verdeling in lees- en perikoopeenhede}

'n Leeseenheid bestaan uit 'n kernsin, met 'n subjek en predikaat. Die kernsin bestaan uit die elemente Subjek - Proses - Objek (Calloud 1976:13). In die identifisering van leeseenhede word die passiewe in aktiewe, en pronominale in nominale vorm oorgeskryf.

\subsection{Identifisering van funksies en kwalifikasies}

Op grond van die perikoopeenhede word 'n lys van die kwalifikasies van elke onderwerp in elke spesifieke stadium van narratiewe ontwikkeling gemaak. Die lys omvat die beskrywing van wat elke onderwerp gebruik of het. Die beskrywing let op die onderwerpe se wil of wat hulle motiveer, hulle waarnemings of watter kennis tot hulle beskikking is, en hulle mag of wat hulle in staat stel om op te tree of te besluit.

\subsection{Beskrywing van pertinente transformasies}

Vervolgens word die stelsel van pertinente transformasies uitgespel. Elke werkwoord in die verhaal manifesteer 'n program van aksie binne die verhaal. Dié programme is nie almal ewe belangrik nie, en slegs enkeles word gebruik om die gang van die verhaal te gebruik. Die verhaal se pertinente transformasies bestaan uit dié programme wat narratiewe prosesse weergee, en 
wat in opposisie tot ander programme binne die verhaal staan. Die opposisie bestaan nie tussen die subjekte of hul toestande nie, maar tussen die funksies. Pertinente transformasies word soos volg beskryf:

- Die verhaal word in terme van asse gelees. Elke as vorm 'n element van die intrige wat van die ander elemente van die intrige onderskei kan word. Die as met die minste programme word eerstens geïdentifiseer. Hieruit word dan die lys van hoof- of polemiese programme bepaal, en opgesom met die formule Subjek (Objek $\rightarrow$ Ontvanger). Die formule (Objek $\rightarrow$ Ontvanger) verteenwoordig die aksie van die narratiewe program wat transformasie is, as 'n proses van die Ontvanger se toestand.

- Hierna word die teks weer oorgelees en die programme van die ander asse geïdentifiseer wat funksies het wat die teenoorgestelde van die programme is wat in die eerste lys uitgestip is.

- $\quad$ Dan word alle programme wat nie pertinent is nie (dit wil sê, wat nie 'n teenoorstaande program het nie), geëlimineer. Nou is dit moontlik om die stelsel van pertinente transformasies op te som in terme van twee programme.

\subsection{Vorming van die semiotiese vierkante}

Hierna word die simboliese stelsel beskryf. Dit word gedoen deur die stelsel van pertinente transformasies van die onderskeie narratiewe vlakke in verband met mekaar te bring. Die verhoudings tussen die onderskeie stelsels van transformasies word in 'n diagram saamgevat. Die stelsels van die interpretatiewe vlakke vorm takke wat uit die stelsel van die primêre tak vloei. Al die polemiese asse word dan opgeswaai sodat die SUBJEKTE van teenoorstaande programme in 'n weersprekende verhouding in die nuut gevormde semiotiese vierkant staan.

Wanneer die intrige of komplot in 'n aktansiële skema of model uitgebeeld word, lyk dit soos volg:

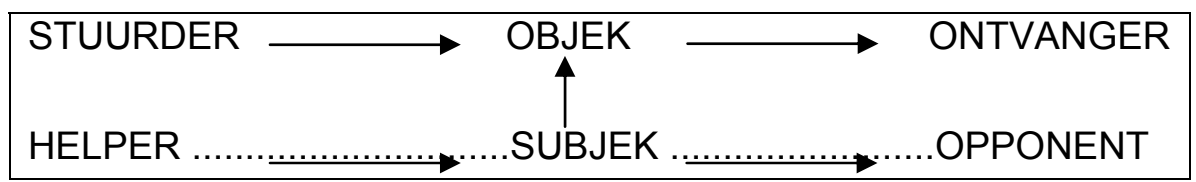




\subsection{Oordrag van waardes of oortuigings}

In 'n volgende stap word gevra na die waardes of oortuigings, of kodes of isotope wat die teks voorstaan. Watter waardes of oortuigings wou die geïmpliseerde skrywer aan die geïmpliseerde lesers meedeel? Waardes word herken aan 'n ononderbroke reeks van semiotiese vierkante, wat aan mekaar verbind is omdat dit aan dieselfde breë semantiese kategorie behoort. ' $n$ Simboliese stelsel bevat een of meer waardes wat onderling verband met mekaar hou. Die assosiasie tussen die onderlinge waardes is paradigmaties van aard, wat beteken dat dit deur verskeie elemente in die teks bekend gestel word, en regdeur die teks voorkom.

\subsection{Identifisering van narratiewe programme}

Die volgende stap bestaan uit die identifisering van die hoof- en polemiese asse deur middel van die identifikasie van die elementêre narratief, en hierbinne van die uiteindelike program. Die struktuur van die narratief bestaan uit 'n netwerk van narratiewe programme (NP). In die netwerk bestaan twee tipes verhoudings tussen die programme: die narratiewe hiërargie wat die logika van narratiewe ontwikkeling weerspieël, en die narratiewe opposisies wat die polemiese dimensie van die narratief vorm (Patte \& Patte 1978:36).

Die elementêre narratief kan in die primêre vlak of in 'n interpretatiewe vlak gevind word. As die uiteindelike program tot die primêre vlak behoort, dui dit die hoof-narratiewe as vir die hele teks aan. Die narratiewe asse waartoe die ander programme in die primêre vlak behoort, kan afgelei word uit hul verhouding tot die uiteindelike program. Indien die uiteindelike program tot 'n interpretatiewe vlak behoort, dui dit slegs die hoof-narratiewe as vir dié spesifieke divergerende narratief aan. Dan moet die uiteindelike program van die primêre vlak steeds geïdentifiseer word. Dié beskrywing maak dit moontlik om die primêre narratiewe vertelling van die verhaal te identifiseer. Die verhaal word in terme van narratiewe programme opgesom (Calloud 1976:26). 'n Narratiewe program is pertinent wanneer dit 'n pertinente transformasie bevat. Dié aksies lei van die aanvanklike tot die finale toestand deur verskeie gebeure. Teenoor die narratiewe program funksioneer 'n antinarratiewe program wat die teenoorgestelde wil bereik. Hieruit word die polemiese karakter van die narratief gebore. Deur te let op die narratiewe en anti-narratiewe programme, kan die ondersoeker gelyktydig die aksies en situasies wat teenoor mekaar staan, beskryf. Die polemiese karakter van 'n teks is dikwels stilgemaak deur die verteller. Dit is nodig om eksplisiet aan te dui wat in die teks geïmpliseer word. Die teks speel 'n selektiewe woordspeletjie om die waardes en teenwaardes wat deur die narratief veronderstel word, te definieer (Patte \& Patte 1978:23-24, 132). 
Om 'n narratiewe program vir die teks te skryf, is dit nodig om te weet wat die situasie en verandering, en wat die verskillende onderwerpe en hulle verhouding tot mekaar is. Om die onderskeie objekte en hulle verhoudings te evalueer, word die narratief in twee narratiewe programme verdeel. Dit word gedoen selfs al lyk dit of die narratief oppervlakkig eenlynig voorkom.

Nadat die narratiewe programme geskryf is, identifiseer struktuuranalise die elementêre narratief, deur 'n onderskeid te tref tussen die hoofnarratief, konvergerende, divergerende asook parallelle narratiewe (Culley 1974:169; Calloud 1976:12-32; Patte \& Patte 1978:34-38; Calloud 1992:118-142). Die narratiewe ontwikkeling moet sorgvuldig ontleed word. Onderbrekings in die formele hiërargiese patroon word aangedui, asook die breuke in die logiese narratiewe ontwikkeling (Patte \& Patte 1978:34-36). Die parallelle narratiewe word uitgeskakel, en die hoof- en konvergerende narratiewe word as die primêre vlak van die elementêre narratief geïnterpreteer. Die divergerende narratiewe word as interpretatiewe vlakke geïnterpreteer. Parallelle narratiewe bevat gebeure wat gelyktydig met die oorspronklike verhaal plaasvind en wat vertel word, al is dit nie verwant aan die vertelling nie. Konvergerende narratiewe word gevind as die formele patroon van 'n elementêre narratief onderbreek word deur 'n vertelling wat 'n bydrae daartoe lewer. In die interseksie van twee narratiewe konvergeer die een in die ander. 'n Divergerende narratief onderbreek ook die formele patroon, maar sonder om die logiese narratiewe ontwikkeling te onderbreek. Dit gebeur as die nuwe narratiewe ontwikkeling gebaseer is op 'n interpretasie van die waarde van die voorafgaande vertelling. Die primêre narratief word verleng maar op 'n ander narratiewe vlak.

Konvergerende narratiewe manifesteer primêr die verhale van helpers, opponente of subjekte van die hoofnarratief. Hier kom dikwels pertinente transformasies voor wat teenoor die transformasies staan wat in die primêre narratief manifesteer. Die hoofnarratief en konvergerende narratiewe manifesteer 'n enkele stelsel van pertinente transformasies: die stelsel van pertinente transformasies van die primêre vlak.

Die laaste stap is om die parallelle narratiewe te bestudeer. Dit word op dieselfde wyse gedoen as in die geval van die elementêre narratiewe. So word die navorser in staat gestel om die simboliese stelsels van die parallelle narratiewe in verband te bring met dié van die elementêre narratiewe.

\section{3. 'N SEMIOTIESE ONTLEDING VAN DANIËL 1}

\subsection{Verdeling in leeseenhede}

Wanneer Daniël 1 in leeseenhede ingedeel word, gee dit die volgende resultaat: 
- $\quad$ Die verhaal word omraam deur 'n verwysing na 'n datum, wat die volle lengte van Daniël se dienstermyn aan vreemde koningshowe aandui. Dit omsluit die ses verhale (Dan 1-6). Die gebruik van die datum om die vertelling in te lui en af te sluit is 'n stylelement wat as inclusio bekend staan.

- $\quad$ Die een en twintig verse kan in twee en veertig perikoopeenhede geanaliseer word.

- $\quad$ Die verdeling in leeseenhede stel die navorser in staat om die teks te hervertaal in terme van subjekte en objekte se funksies (wat hulle doen) en kwalifikasies (wat hulle is of het), wat die volgende stap in die struktuur-analise is.

\subsection{Funksies en kwalifikasies}

Die analisering van die perikoopeenhede stel die navorser in staat om die teks in terme van funksies (wat gebeur) en kwalifikasies (wat is) te analiseer. Hieruit vloei die volgende gevolgtrekkings:

- Die agente aan wie kwalifikasies toegeskryf word, is die jongmanne, die beampte en die Jode. Die jongmanne moet aan twee vereistes voldoen, waaraan die vier Jode by uitstek voldoen. En die beampte is bang dit gebeur nie. Die ongekompliseerdheid van kwalifikasies dui op die eenvoud van die verhaal. Slegs een saak kom daarin te berde.

- $\quad$ Die handelende agente is ook beperk. Daar word tien maal na die koning se aktiwiteite verwys, agt maal na die opsiener en vyf maal na die hoofpaleisbeampte, ses maal na Daniël, vyf maal na die jongmanne en drie maal na die Jode se God. Verwysings na die vier Jode kom slegs drie maal voor. Daar is min komplikasies in die verhaal. Die intrige verloop redelik reglynig, met 'n konstante stygende spanningslyn.

- Die grootste klem in die verhaal val op "doen”. Dit is 'n kort kortverhaal. Min ruimte word aan die beskrywing van toestande afgestaan. Dit gaan om transformasies. Daar is nie veel ruimte oor vir beskrywing nie.

- Dié analise stel die navorser in staat om die transformasies, wat in die verhaal voorkom, te ondersoek. 


\subsection{Pertinente transformasies}

Die vraag is: watter transformasies is pertinent? Die volgende blyk sewe pertinente transformasies te wees, omdat dit op binêre opposisies gebaseer is:

7 koning roep jongmanne voor hom

6 God gee insig en wysheid aan Jode

5 amptenaar weier dieet

4 Daniël vra vergunning van amptenaar

3 koning gee aan kwekelinge kos en wyn

2 koning beveel Aspenas tot seleksie

1 die koning beleër Jerusalem beampte bring jongmanne

koning vind niemand soos Jode opsiener laat eksperiment toe God maak beampte gunstig Daniël neem voor om nie kos te gebruik

Aspenas bring vier Jode

God gee stad en volk in sy hand

Die pertinente transformasies verteenwoordig die binêre opposisies wat binne die verhaal se intrige 'n rol speel. Die eerste twee (1-2) en die laaste transaksie (7) het te doen met die agtergrond van die verhaal, en dra nie tot die intrige by nie. Die middelste vier transaksies of transformasies vorm die intrige. Om dié rede val die soeklig verder op dié vier transformasies.

\subsection{Rolspelers}

Die rolspelers in die intrige is belangrik: die koning gee en Daniël weier om te neem, Daniël vra en God maak gunstig, die amptenaar weier en die opsiener laat toe, God gee en die koning vind. Die verband tussen die twee stellings is baie belangrik. Dit kan soos volg opgesom word:

koning - voorsiening

Daniël - versoek

amptenaar - weiering

God - skenking
Daniël - weiering (vv 5, 8)

God - gunstigmaking (vv 8, 9)

opsiener - toelating ( vv 10, 14)

koning - toe-eiening (vv 17, 19)

Wanneer die aksies van die aktante met Calloud (1976:24) se klassifikasie van aksies vergelyk word, gee dit die volgende resultate: 


\section{'n Semiotiese ontleding van Daniël 1}

- $\quad$ voorsiening = somatiese daad;

- $\quad$ weiering = oortuigende daad;

- $\quad$ versoek = kommunikatiewe daad;

- $\quad$ goddelike gunstigmaking = oortuigende daad;

- $\quad$ weiering = interpretatiewe daad;

- $\quad$ toelating = interpretatiewe daad;

- $\quad$ skenking = somatiese daad;

- $\quad$ toe-eiening = interpretatiewe daad.

Die gevolgtrekking is dat die aksies wat in Daniël 1 beskryf word, alle aksies omvat wat Calloud vir vertellings voorstel. Die verhaal van Daniël 1 bevat baie aksies, en min beskrywings.

\subsection{Intrige}

Die beskrywing van aksies in Daniël 1 kan ook volgens Calloud se klassifikasiestelsel in terme van die ontwikkeling van die intrige gedefinieer word. Die intrige begin met die koning wat kos vir die kwekeling-wyses gee (somatiese daad), terwyl Daniël hom voorneem om die kos nie te gebruik nie (interpretatiewe daad). Die oplossing van die intrige bestaan daarin dat God aan die vier Jode wysheid gee, wat daartoe lei dat die koning niemand soos die Jode vind nie (oortuigende daad). Struktureel suggereer die verhaal dat daar 'n direkte verband tussen Daniël se voorneme, en die waarneming van die koning is dat niemand so goed soos die vier Jode is nie. Die leser sien dié verband wanneer hy let op die wyse waarop die verhaal saamgestel is.

Twee stellings wat paradoksaal langs mekaar staan, is dat God die hoofpaleisbeampte gunstig gesind maak ( $v$ 9), maar dat die beampte nogtans weier om Daniël se versoek toe te staan. Historiese kritiek wys die duidelike weerspreking uit as die produk van 'n latere redakteur, wat verskeie tradisies byeengebring het. Die redakteur het nie die soom wat in die verhaal bestaan het, tydens die redaksionele proses uitgestryk nie (Aichele et al 1995:21). Die weerspreking tussen God wat die hoofpaleisbeampte gunstig gesind maak, en die beampte wat nie gunstig na Daniël se versoek luister nie, kan egter as 'n stylelement verklaar word. Die verteller benut die weerspreking doelbewus om die spanning te laat opbou. Net sodra die leser meen Daniël se probleem is opgelos (God het immers ingegryp), lees hy dat die beampte redes verskaf hoekom hy nie die dieet kan verander nie. 


\subsection{Semiotiese vierkante}

Wanneer die transformasies as semiotiese vierkante voorgestel word volgens Greimas (1983:25) se model, lyk dit soos volg:

God gee wysheid vir die Jode

beampte weier

Daniël vra vergunning

koning gee kos koning vind Jode die beste

opsiener laat toe

God maak gunstig

Daniël weier kos

Dit is opvallend dat al die aksies in verse 8-16 voorkom. Die gegewens in verse 5, 17 en 19 lig slegs die transformasies in verse 8-16 toe. Verse 8-16 bevat die beskrywing van die intrige. Verse 1-7 asook 17-21 verskaf die agtergrond-inligting (wat te doen het met die eerste hoofstuk se inleidende funksie).

Wanneer die intrige of komplot in so 'n aktansiële skema vervat word, speel die koning en sy verteenwoordigers die aktansiële rol van opponente. Die verteenwoordigers is die hoofpaleisbeampte en opsiener. Dit is so, ten spyte van die koning se goeie bedoeling om aan die kwekelinge net die beste sorg te verskaf. Die aktant van subjek word deur Daniël en sy vriende vervul, en die objek is "manne wat voor die koning kan staan", of paleisamptenare. Die helper is die amptenaar, maar ook God. Die skema lyk soos volg:

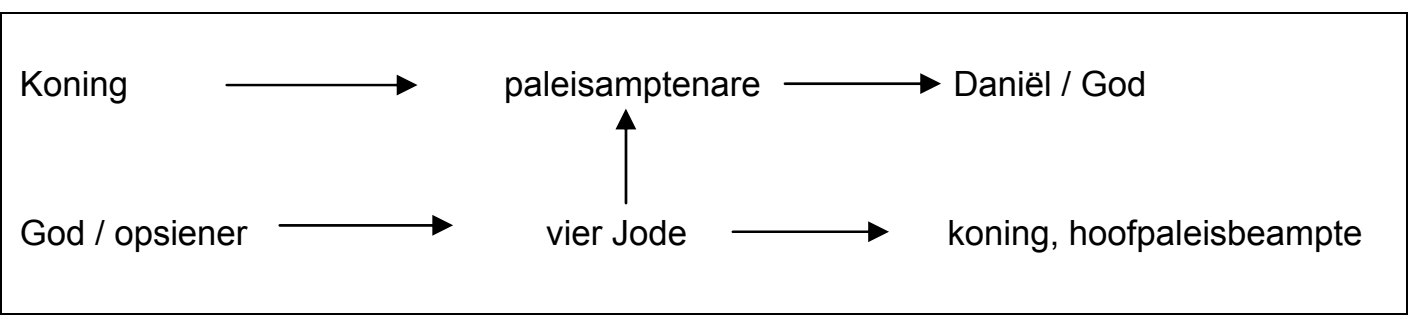

\subsection{Oordrag van waardes of oortuigings}

Die volgende vraag wat die semiotiese ontleding aan die verhaal stel, het te doen met die waardes of oortuigings (kodes of isotope) wat die teks voorstaan en aan die eerste lesers meedeel. Dit is essensieel aan die filosofie van 


\section{'n Semiotiese ontleding van Daniël 1}

struktuur-analise dat dié waardes ook deur latere lesers herken sal word, omdat struktuur onderliggend aan mens-wees is.

Die belangrike waardes draai om soewereiniteit en verantwoordelikheid. Aan die een kant word die Jode se verantwoordelikheid in die nuwe situasie van 'n heidense hof beskryf. Hier aanvaar hulle verantwoordelikheid vir hulle bestemming, en by implikasie vir dié van hulle volk. Hulle verantwoordelikheid hou egter nie hier op nie. Hulle is deur God aan 'n vreemde hof geplaas, en word geroep om getrou aan die God van hulle voorvaders te wees.

Hulle getrouheid is 'n voorwaarde dat God se seën op hulle rus. Dit is ook 'n voorwaarde dat die vreemde koning en sy hof hulle God se soewereiniteit sal ervaar en erken (vgl ook in Dan 2:47; 3:28-29; 4:2-3, 34-35 asook 6:27-28).

Die tweede waarde het met die soewereiniteit van God te make. Hy is die Een wat gee - Hy gee sy stad, en sy tempel se voorwerpe in die hand van die vreemde koning. En Hy gee wysheid aan dié mense wat aan Hom getrou bly, deur hulle nie met die koning se kos en wyn te verontreinig nie.

Alhoewel Daniël 1 nie met 'n indrukwekkende koninklike verklaring en belydenis van God se soewereiniteit eindig (of begin, soos in Dan 4) nie, weet die eerste lesers daarvan. Die hele verhaal staan in die teken daarvan. God is die Een wat die aksie bepaal. Die Jode sou nie in ballingskap wees as God hulle nie weggegee het nie. Die hoofpaleisbeampte sou nie gunstig gesind teenoor die Jode gewees het as God nie die gunstigheid gegee het nie. Die Jode sou nie aan die hof aangestel word as God nie wysheid gegee het nie. God is die Een wat die gang van gebeure bepaal. Hy is soewerein.

\subsection{Narratiewe programme}

Die verhaal kan ook op 'n ander manier in terme van sy opposisies beskryf word. Dan kan die primêre narratiewe vertelling daaruit gedemonstreer word. Die verhaal word in terme van narratiewe programme opgesom. Die transaksies waaruit die verhaal bestaan, is:

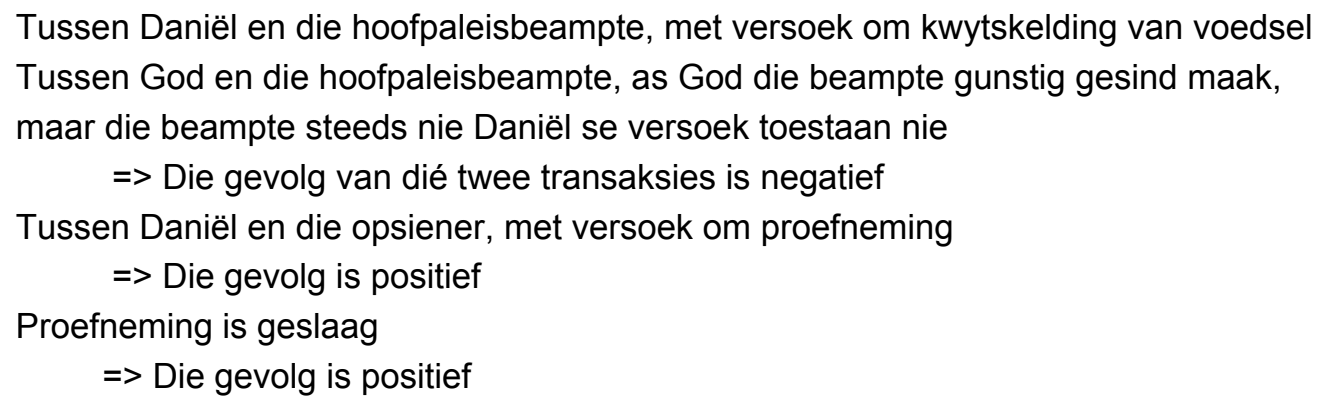


Die transaksies gaan dus om:

\begin{tabular}{|c|c|c|}
\hline Koning gee kos & $>$ & Daniël besluit om hom nie te verontreinig nie \\
\hline Daniël vra toestemming & $=>$ & Hoofpaleisbeampte weier toestemming \\
\hline God maak gunstig & $=>$ & Hoofpaleisbeampte weier \\
\hline Daniël vra toestemming & $=>$ & Opsiener gee toestemming \\
\hline Joodse ballinge eet groente & $=>$ & Ander jongmanne eet koning se kos \\
\hline
\end{tabular}

Wanneer dit in terme van narratiewe programme vertaal word, lyk dit soos volg:

NP1 koning beleër en verower Jerusalem, onderwerp dit en voer ballinge en tempelgereedskap weg na Babel ( $v 1$ )

NP2 Here gee Jerusalem in koning se hand ( $v 2$ )

NP3 koning beveel dat jongmanne opgelei word om aan sy hof diens te doen ( vv 3-5)

NP4 vier Joodse jongmanne word gewerf en opgelei (vv 6-7)

NP5 koning bepaal wat kwekelinge eet en drink ( $v 5$ )

NP6 Daniël onderneem om nie die koning se kos en wyn te eet en te drink nie ( $(\mathrm{r})$

NP7 Daniël onderhandel met opsiener, sonder sukses (vv 9-10)

NP8 Daniël onderhandel met beampte, suksesvol (vv 11)

NP9 Daniël vra dat proefneming gedoen word (vv 12-13)

NP10 eksperiment word gedoen, en is geslaag ( $v v 14-15)$

NP11 beampte neem koning se kos weg (v 16)

NP12 beampte gee net groente (en water) ( $\vee 16)$

NP13 God gee aan vier Jode wysheid en insig ( $v 17$ )

NP14 God gee aan Daniël uitlegvermoë (v 17)

NP15 koning toets jongmanne (vv 18-19)

NP16 koning bevind niemand so goed soos Joodse jongmanne ( $\mathrm{v} 19$ 20)

NP17 Jode dien koning ( $v 21)$

NP18 Daniël dien vir baie lank onderskeie konings (v 21) 
Om op te som, die primêre narratiewe program is:

Die koning bepaal wat die kwekelinge eet en drink, en Daniël weier om dit te doen.

Die feit dat Daniël weier om die koning se kos te eet (of: om hom te verontreinig), lei tot die volgende program:

God gee aan die Jode wysheid en insig.

Die implikasie is duidelik: omdat die Jode getrou bly, gee God aan hulle die gawes wat nodig is om aan die vereistes te voldoen wat nodig is om aan die hof aangestel te word. Dat God wysheid en insig aan die Jode gee, voltooi die primêre narratiewe program:

Die koning sien hulle uitsonderlike vaardighede raak en stel hulle aan.

Die intrige speel binne die primêre narratiewe program af. Die intrige bestaan uit Daniël se versoek aan die hoofpaleisbeampte asook opsiener, en die proefneming wat daaroe lei dat die Jode hul eie dieet mag volg.

\subsection{Verskillende narratiewe binne die vertelling}

Nou is dit moontlik om die ineengeweefde narratiewe binne die vertelling te identifiseer. Die inligting in die eerste vers bevat 'n divergerende narratief deurdat dit 'n interpretasie bevat van die verhaal wat daarop volg. Deur die omstandighede te skets waarbinne die verhaal afspeel, dra dit nie direk tot die aksie by nie. Die primêre narratief van Daniël 1 word gevind in:

- $\quad$ verse 3-4 wat vertel van die soektog na geskikte jongmanne uit die ballinge wat tempeldiens kan verrig;

- $\quad$ verse $5 \mathrm{~b}$ en c wat vertel van die opleiding;

- $\quad$ vers 6 wat vertel dat daar drie Joodse jongmanne gewerf is;

- $\quad$ verse 18 tot 20 wat vertel hoe die vier jongmanne deur die koning getoets, en geskik bevind is vir tempeldiens.

Die vertelling in verse 8-16 vorm 'n konvergerende narratief deurdat dit gebeure bevat wat gelyktydig met die oorspronklike verhaal plaasvind. Dit lewer 'n bydrae tot die hoofnarratief. Waaruit bestaan dié bydrae tot die hoofnarratief? Die vertelling van Daniël se besluit om hom nie met die koning se kos te verontreinig nie, mag lyk of dit nie veel met die verhaal oor die aanstelling van hofamptenare te doen het nie. Dan vorm die vertelling oor Daniël se besluit oor die kos nie 'n essensiële deel van die verhaal oor die aanstelling van hofamptenare nie. As dit so is, vorm verse 8-16 'n parallelle 
narratief. Ek meen egter dat dit 'n belangrike bydrae tot die hoofnarratief lewer, al word die verband tussen die aanstelling van hofamptenare en Daniël se besluit oor die koning se kos nie duidelik uitgespel nie. Daniël word as die beginselvaste persoon voorgestel. Die implikasie bestaan dat hy ter wille van sy godsdienstige oortuigings die besluit neem - hy besluit immers om hom nie met die kos te verontreinig nie.

Nog 'n konvergerende narratief kom in vers $5 a$ voor. Die skrywer vertel dat die koning die kos en wyn vir die kwekelinge verskaf het. Dié mededeling word gemaak wanneer die skrywer die opleidingsgebeure skets. Vers $5 a$ se mededeling is belangrik vir die gang van die verhaal en vorm soos verse 8-16 'n konvergerende, en nie 'n parallelle narratief nie.

Konvergerende narratiewe kom ook in verse 2 en 17 voor. In vers 2 word 'n teologiese uitspraak gemaak dat dit God was wat Jojakim en 'n deel van die tempelgereedskap in die Babiloniese koning se hand oorgegee het. Nebukadnesar het die tempelgereedskap na sy eie land weggevoer en in die tempel van sy god geplaas. Vers 17 bevat weer eens 'n teologiese uitspraak: dit is God wat aan die Joodse ballinge wysheid en insig gegee het, sodat hulle baie slimmer as die ander howelinge was.

Parallelle narratiewe kom in vers 7 voor, wat verwys na die vernoeming van die vier Jode, asook in vers 21 , wat aandui dat Daniël vir baie jare in koninklike diens gebly het, tot die begin van die regering van Kores. Dié mededelings is parallel aan die hoofnarratief omdat dit gebeure beskryf wat gelyktydig met die oorspronklike vertelling plaasvind. Dit word vertel al is dit nie aan die hoofnarratief verwant nie.

Die parallelle narratief bestaan uit twee elemente: die hoofpaleisbeampte gee vir die vier Joodse jongmanne nuwe name (vv 6-7), en Daniël se diens aan die paleis word temporeel beskryf ( $v 21$ ). Die waarde van die eerste mededeling is simbolies van aard. Dit dra die betekenis van lojaliteit en trou wat verskuif moet word na iets of iemand anders. Die waarde van die tweede mededeling is om aan te dui dat die Jood wel aan diens gebly het. Hierteenoor sal die konvergerende narratief aandui hoe die Joodse jongmanne hulle trou nie verskuif het van hulle eie godsdiens en kultuur na die Babiloniese nie. Dit word met die hoofnarratief gebalanseer wat vertel hoe die Jode met onderskeiding in tempeldiens aangestel is, en presteer het.

Die hoof-, konvergerende en divergerende narratiewe staan in noue verwantskap deurdat dit bydra tot die narratiewe ontwikkeling van die elementêre narratief. 
Die konvergerende narratief kan beskryf word in terme van:

- $\quad$ SUBJEK: Daniël (en sekondêr, sy drie vriende, omdat hulle nie die versoek rig nie);

- $\quad$ OPPONENT: koning en sy verteenwoordiger, die hoofpaleisbeampte;

- $\quad$ HELPER: hoofpaleisbeampte (tot sekere mate) en opsiener.

Die helpers van die held is in beide gevalle aanvanklik onwillig. Dat hulle helpers is, word toegeskryf aan die feit dat God die helper goedgesind en gunstig teenoor Daniël maak ( $v$ 9).

'n Element wat spanning in die verhaal skep, is die kos wat die koning verskaf, teenoor die kos wat die Joodse ballinge wil eet. Waar pas dié element in by die res van die verhaal? Om dié vraag te beantwoord, moet die primêre narratief vervolgens ondersoek word.

In die hoofnarratief word vertel hoe die koning, soos skynbaar gebruik was wanneer hy volke aan sy mag onderwerp het, onder die Joodse volk jongmanne soek wat in sy diens kan staan. Die koning stel verskeie vereistes waaraan die jongmanne moes voldoen. Onder die jongmanne wat gewerf word, was daar vier vriende. Wanneer hul opleiding voltooi is, slaag die vier jongmanne met vlieënde vaandels. Hulle is baie beter as die ander amptenare aan die hof vir sover dit wysheid en insig betref.

Die enigste pertinente transformasie wat hier voorkom, bestaan tussen die vlak van wysheid wat die vier Joodse kwekelinge voor en na hulle opleiding vertoon. Die skrywer gee egter geen inligting oor die vlak van wysheid of insig wat die jongmanne vóór hulle opleiding gehad het nie. Hy sê wel dat hulle vlak van wysheid en insig aan die einde van die opleiding baie hoër was as dié van hulle tydgenote. Om dit te verduidelik, word daar van 'n konvergerende narratief gebruik gemaak: vers 17 noem dat God die wysheid en insig aan hulle gegee het. Die opmerking dat God aan Daniël ook die vermoë gegee het om drome en gesigte uit te lê, is nie onmiddellik relevant nie. Dit het met die verhaal se inleidende funksie tot die res van die verhalekorpus te doen.

Die binêre opposisie in die primêre narratief bestaan tussen die Joodse jongmanne en die ander (heidense) howelinge. Dit is die opposisie tussen die mens wat God se guns geniet en die mens wat sonder Hom leef. Die aansluiting in waarde met die konvergerende narratief oor die voedsel is duidelik: dit gaan om trou en lojaliteit aan God. In die konvergerende narratief word die eis om lojaliteit deur die aanbieding van voedsel gestel. Die vier Joodse jongmanne slaag die toets deur getrou aan hulle God te bly. In die hoofnarratief word verduidelik dat die vier jongmanne aan die hof aangestel 
word. As die verteller nie die konvergerende narratief byvertel het nie, sou die leser alle rede gehad het om te meen dat die Joodse manne hulle lojaliteit aan Nebukadnesar toegesê het.

Dat die jongmanne se besluit oor die kos, en die hele kwessie van hulle aanstelling aan die hof 'n godsdienstige dimensie het, word deur die ander twee konvergerende narratiewe bevestig ( $v v 2$ en 17). Dit het te doen met die funksie van twee belangrike werkwoorde wat elke keer aan 'n spesifieke persoon gekoppel is: om te gee en om te neem. Die een wat neem is Nebukadnesar, terwyl die Joodse God die een is wat gee. Hy gee die Jood in Nebukadnesar se hand, en Hy gee aan Daniël en sy vriende wysheid.

Die plasing van God in die verhaal, net voor die hoofnarratief begin en net voor die hoofnarratief ten einde loop ( $v v 1$ en 17), laat die leser vermoed dat die skrywer doelbewus wou beklemtoon dat dit die beslissende gebeure in die verhaal is. Die verhaal sou nie kon gebeur as dit nie vir dié twee opmerkings was nie: God gee die Jood weg ( $v 1)$, en Hy gee vir vier Joodse jongmanne wysheid en insig ( $v 17)$.

Die waardes wat deur dié narratiewe onderstreep word, is dat nòg Nebukadnesar nòg die vier Jode enigiets sou kon bereik as dit nie was dat God gegee het nie. So stel die vertelling die tema van God se soewereiniteit aan die orde. Dit word gedoen deur die verhaal te plaas teen die agtergrond van die soewereiniteit van die grootste koning van die dag. Nebukadnesar neem besluite en gee opdragte. Hy oorwin volke en voer hulle in ballingskap weg. Sy mag raak ook die Joodse volk. Daniël 1 beklemtoon dat die Jode se God gee, en dat Hy die Een is wat werklik soewerein regeer. Die pertinente transformasies vind in die konvergerende narratiewe plaas en verduidelik die belang daarvan vir die hoofnarratief.

\subsection{Temas}

Uit die analise van die narratief het dit duidelik geword dat die verhaal uit die volgende temas opgebou is:

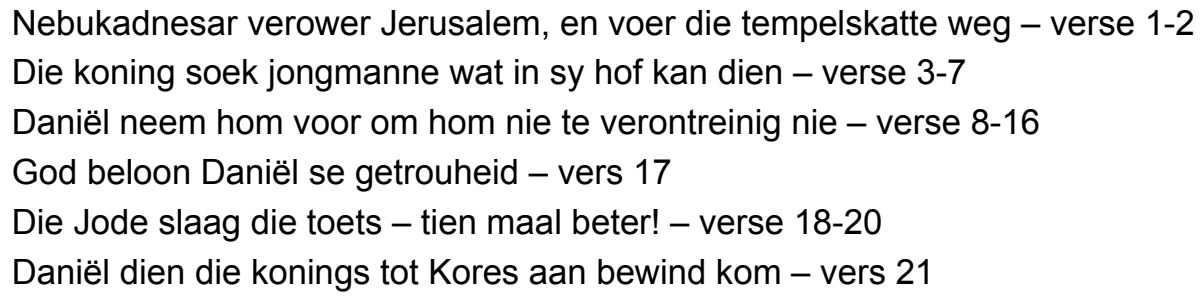




\section{'n Semiotiese ontleding van Daniël 1}

Die eerste en laaste verse van Daniël 1 dui verskillende konings se regeringstye aan. Daniël kom in Babel aan in die derde regeringsjaar van Nebukadnesar. Hy staan in regeringsdiens tot in die eerste jaar van Kores. Dié twee datums het simboliese betekenis. Dit dui die begin en einde van die ballingskap aan. Dit beteken dat Daniël vir die volle lengte van die ballingskap weggevoer was. Daniël word ' $n$ simbool van die volk in ballingskap.

Ná die inleiding (vv 1-2) gee die koning opdrag dat jongmanne vir opleiding gesoek moet word. Die kwalifikasies waaraan hulle moet voldoen, word beskryf. Hierna stel die skrywer die leser aan die vier Jode voor. Na die deel wat oor die verskaffing en weiering van kos handel (vv 8-16), vertel die skrywer wat die uitslag van die opleiding is, en hoe die koning die vier Jode in die hof aanstel.

Sentraal in die gebeure staan Daniël se besluit om hom nie met die kos te verontreinig nie, asook sy onderhandelings om dit nie te eet nie. Hierna word beskryf hoe God die Jode vir hulle getrouheid beloon. Die verhaal bevat dus 'n ringskomposisie:

\begin{tabular}{|ll|}
\hline A1 & \multicolumn{1}{l|}{ tydsaanduiding: begin van ballingskap } \\
& B1 $\quad \begin{array}{l}\text { jongmanne uitgesoek vir paleisdiens } \\
\text { C1 } \quad \text { Daniël se besluit oor kos, proefneming en uitslag } \\
\text { C2 } \quad \text { God gee wysheid }\end{array}$ \\
& $\begin{array}{l}\text { B2 } \quad \text { toets voor koning, jongmanne in paleisdiens } \\
\text { A2 }\end{array}$ tydsaanduiding: einde van ballingskap \\
\hline
\end{tabular}

Die fokuspunt van die verhaal lê in die middelste vertelling (C1 en C2). Dit vertel van Jode wat in ballingskap voor die versoeking kom om aan die koning se tafel te eet. Ter wille van hulle geloof weier hulle. God beloon hulle.

Daniël 1 se verteling sentreer om twee fokuspunte: wysheid en voedsel. Vers 4 gebruik vyf begrippe om wysheid te omskryf. En in die sewentiende vers kom vier begrippe voor. In die twintigste vers kom twee begrippe voor. Vers 17 skryf die vierde begrip ("uitleg van drome en visioene") slegs aan Daniël toe. Die term kom net hier in die hele hoofstuk voor. Vir die Babiloniese wyse manne was die uitleg van drome en gesigte deel van hulle wysheidstradisie. Die tweede hoofstuk sal egter verduidelik dat menslike wysheid nie sover strek nie. Die toekoms is slegs aan God bekend. En Hy maak dit bekend aan wie Hy wil. Die term "uitleg van gesigte en drome" dien ' $n$ inleidende funksie. Dit bied ' $n$ belangrike sleutel tot die verstaan van Daniël 2. 
Die tweede fokuspunt is voedsel. Die jongmanne kry die geleentheid om van die kos en wyn van die koning se tafel te eet ( $v v 5,8,10,13,15,16)$. Daniël en sy vriende verkies groente en water, en vertoon tien maal beter ( $v \mathrm{v}$ 12 en 16). Die twee temas bepaal die gang van die verhaal. Die jongmanne word opgelei om as wyses diens te doen. Die vier Jode weier die koning se kos. Hulle word vir hul toewyding aan God met wysheid beloon.

Wanneer Daniël vir die hoofpaleisbeampte sê dat hy nie die koning se kos wil gebruik nie, verskaf die hoofpaleisbeampte redes hoekom dit belangrik is dat Daniël wel die kos eet. Daniël reageer op die weiering deur na die amptenaar te gaan, en 'n ander invalshoek te gebruik. Die hoofpaleisbeampte se argument was dat hy dit nie kan toelaat nie, omdat die Jode se voorkoms swakker as die ander jongmanne sal vertoon. Daniël vra dat 'n eksperiment gedoen word om te bepaal wie die beste gaan lyk na tien dae: die jongmanne wat die koning se kos eet of die Jode wat groente eet. Die opsiener laat dit toe. Die uitslag van die toets haak die knoop deur sodat Daniël hom by sy voorneme kan hou. Verse 18 tot 20 beskryf hoe al die jongmanne voor die koning kom, en dat die vier Jode die toets met vlieënde vaandels slaag.

\subsection{Karakters}

Die karakters wat die grootste rol in die verhaal speel, is die hoofpaleisbeampte wat saam met sy opsiener die koning se opdrag uitvoer. Aan die ander kant staan die vier Jode wat die opdrag nie ten volle gehoorsaam nie. Nog 'n rolspeler is die Here (so in v 2 genoem) of God (vv 9 en 17). Sy rol word beperk tot die subjek van die een werkwoord: om te gee. Hy gee Jerusalem weg. Hy gee guns aan Daniël by die hoofpaleisbeampte en Hy gee aan haar kinders wysheid (verse 2, 9 en 17). Passiewe karakters wat nie optree nie, is Jojakim en Nebukadnesar se gode (2), asook die towenaars en voorspellers (v20).

Die skrywer skep 'n kontras tussen die gode van Nebukadnesar en die God van Daniël, wat struktureel voorgestel soos volg lyk:

$\vee 2$ God gee Jerusalem in Nebukadnesar se hand

v $2 \quad$ verwysing na Nebukadnesar se god, tempel en skatkamer vv 6, 11, 14 vier Jode se name met die teofore element

v 7 die vier se nuwe name met die (vermeende) verwysing na Babel se gode

Die oneweredigheid tussen die rol wat die Jode se God en Babel se gode speel, is duidelik. Dit is betekenisvol dat die Joodse teofore name vir die vier 


\section{'n Semiotiese ontleding van Daniël 1}

Jode in vers 19 gebruik word, wanneer die jongmanne voor die koning verskyn. Die saak wat in die hoofstuk onder die loep geneem word, gaan nie om die Babiloniese gode nie. Die gevaar vir die Jode is nie afgodery nie. Die gevaar is dat hulle hul toewyding aan God kan kompromitteer deur nie die bepalings van sy Tora te onderhou nie.

Die skrywer gebruik die mededeling oor die naamsverandering ironies. Die koning se verteenwoordiger gee aan die ballinge nuwe name om hulle hulle identiteit te ontneem. Die ballinge moet in 'n nuwe samelewing 'n nuwe rol vervul. Die gevaar was vir die vier Jode wesenlik dat hulle in die proses van ontkulturering en verinheemsing hulle Joodse identiteit kon verloor. Hulle sou dan ook hulle lojaliteit aan die God van hulle voorvaders inboet. Die verhaal in Daniël 1 wil egter beklemtoon dat Daniël vir 'n godsdienstige beginsel opkom, en sy Joodse naam verdien (in v 19).

\section{SINTESE}

In dié artikel is die werkswyse van semiotiek kortliks beskryf voor dit op Daniël 1 van toepassing gemaak is. Uit die semiotiese ontleding blyk dit dat die intrige van Daniël 1 daaruit bestaan dat die koning gee en Daniël weier om te neem, Daniël vra en God maak gunstig, die amptenaar weier en die opsiener laat toe, God gee en die koning vind. Die koning en sy verteenwoordigers speel die aktansiële rol van opponente, die aktant van die subjek is Daniël en sy vriende, die objek is die paleisamptenare en die helper is die amptenaar, maar ook God. Die belangrike waardes wat oorgedra word, is God se soewereiniteit en gelowiges se verantwoordelikheid. Die primêre narratiewe program bestaan daaruit dat die koning bepaal wat die kwekelinge eet, Daniël weier om dit te doen, God gee aan die Jode wysheid en insig, en die koning sien hulle uitsonderlike vaardighede raak en stel hulle aan. So is die twee fokuspunte van die verhaal voedsel en wysheid. Die gevolgtrekking is dat die werkswyse nut het in die interpretasie van die verhaal in Daniël 1.

\section{Literatuurverwysings}

Aichele, $\mathrm{G}$ et al 1995. The postmodern Bible. New Haven, CT: Yale University Press. (Bible and Culture Collective.)

Amerding, C E 1997. The Old Testament and criticism. Biblical and Theological Classics Library. Carlisle: Paternoster.

Atkins, G D \& Morrow, L (eds) 1989. Contemporary literary theory. Amherst: University of Massachusetts Press.

Calloud, J 1976. Structural analysis of narrative, tr by D Patte. Philadelphia, PA: Fortress. 
Calloud, J 1992. A few comments on structural semiotics: A brief review of a method and some explanation of procedures, in House, P R (ed), Beyond form criticism, 118-142. Winona Lake, IN: Eisenbrauns. (Essays in Old Testament Literary Criticism.)

Culley, R C 1972. Some comments on structural analysis and biblical studies. Congress Volume: Uppsala, Vetus Testamentum Supplements 22, 129-142. Leiden: Brill.

Culley, R C 1974. Structural analysis: Is it done with mirrors? Interpretation 28, 169184.

Culley, R C 1992. Themes and variations. A study of action in biblical narrative. Atlanta, GA: Scholars Press. (The Society of Biblical Literature Semeia Studies.)

Greimas, A J 1983. Structural semantics: An attempt at a method, tr by D McDowell, R Schleifer \& A Velie. Lincoln: University of Nebraska Press.

Jacobson, R 1974. The structuralists and the Bible. Interpretation 28, 147-156.

Milne, P J 1988. Vladimir Propp and the study of structure in Hebrew Biblical narrative. Sheffield: Almond Press. (Bible and Literature Series.)

Muilenberg, J 1969. Form criticism and beyond. Journal of Biblical Literature 88, 828.

Patte, D \& Patte, A 1978. Structural exegesis: From theory to practice. Exegesis of Mark 15 and 16. Philadelphia, PA: Fortress Press. (Hermeneutical implications.)

Polzin, R 1975. "The ancestress of Israel" in danger. Semeia 3, 81-96.

Spivey, R A 1974. Structuralism and Biblical Studies: The uninvited guest. Interpretation 28, 104-145.

Weiss, M 1972. Die Methode der "Total Interpretation". Congress Volume: Uppsala, Vetus Testamentum Supplements 22, 88-112. Leiden: Brill. 